Vol. 5, No. 2, 2018

https://doi.org/10.23939/eem2018.02.067

UDC 330.016

A. Chushak-Holoborodko

$\mathrm{PhD}$ in Economics, Associate professor

O. Didukh

$\mathrm{PhD}$ in Economics, Senior lecturer

R. Zaderetska

$\mathrm{PhD}$ in Economics, Assistant professor

Lviv Polytechnic National University

\title{
DETERMINING THE EFFICIENCY OF THE FINANCIAL OUTSOURCING USE BY AN ENTERPRISE-CUSTOMER
}

\begin{abstract}
The article disclosed the essence of the financial outsourcing and its place in the outsourcing activity system of an enterprise-customer. It is determined that financial outsourcing can be considered as one of the subspecies of management processes outsourcing. The delegation of financial functions to the third-party organization has a number of advantages, but this is also rather risky considering the importance of such a function qualitative performing. That is why the determination of financial outsourcing efficiency is an important task. So it is proposed to use a complex of indicators, as it would enable consideration of all peculiarities of this activity. To determine the result of delegating the financial functions to outsourcer, one should first of all estimate the cost efficiency of such an activity. It is also important to compare rate of growth in profits and income before and after outsourcing implementation. We should mention that different functions, which are being delegated to the third-party, influence on different sides of enterprise-customer activity, so the system of indicators is being determined and the main of them have been calculated by the example of domestic enterprises.
\end{abstract}

Key words: outsourcing, financial outsourcing, outsourcing activity, outsourcing cost efficiency, indicators of outsourcing efficiency.

\section{Problem statement}

Outsourcing use at the Ukrainian enterprises became a prerequisite for their activities optimization. Modern economic conditions stipulate for the necessity of cost reduction and the certain functions duration shortening with the preservation of the required quality level of products and services that are provided to the consumer. One of the outsourcing types, which is being actively implemented by the domestic and foreign enterprises today is the financial outsourcing. So the evaluation of this type of outsourcing use efficiency by the enterprise-customer is an important task in order to avoid unpredictable financial consequences, in particular, the situation, when delegation of some functions to outsourcer is ineffective.

\section{Relevance of the selected topic}

In the domestic economy conditions, the financial outsourcing use sometimes is riskier comparing with another types of outsourcing, since in this case the information about financial and accounting calculations is being transmitted. So the formation of mechanism for determining the efficiency of some financial functions delegation to the third-party organization is urgent.

\section{Analysis of the recent researches and publications}

The investigation of the essence and evaluation features of the financial outsourcing use have been realized by many scientists, such as O. Lohvinova, A. Isavnin, V. Kosmina, O. Kalendzhian, L. Omelchenko, O. Laktyonova, N. Mandra and others. However, in the studies of both native and foreign scientists only the certain aspect of outsourcing efficiency determination is very often considered, and consequently the comprehensive 


\section{Chushak-Holoborodko A., Didukh O., Zaderetska R.}

approach, which would reckon all the peculiarities of this activity, is absent.

\section{Purpose and tasks}

The aim of the article is to develop a comprehensive approach for determining the efficiency of financial outsourcing use by the domestic enterprises-customers.

\section{Exposition of the main research material and the results obtained}

Generally outsourcing is an instrument of the enterprise production and economic activities management, which provides for the delegation to the third-party organization of a part of both secondary and main functions on the basis of the established contract and for a certain fee; it stipulates for the entrepreneurial activities optimization and in some cases, for the additional involvement of employees, and is directed on the activities competitiveness increasing. So we may conclude that the financial outsourcing is one of the outsourcing types, which provides for the realization of financial functions by the third-party organization or the involved external employee in accordance with the established contract and for a certain fee. Interconnection and a place of the financial outsourcing in the enterprise outsourcing activities in general is shown in Fig. 1.

Sufficiently exhaustive and complete definition of financial outsourcing types was presented by O. Bilotserkivkii and Yu. Chudnovets. In parti- cular, they singled out: outsourcing in accounting; outsourcing in taxation; outsourcing in the sphere of banking services; outsourcing in the field of financial-investment and financial-economic analysis; outsourcing in management (accounting, control, incomes and costs planning, analysis of financial indicators etc.). This classification of financial outsourcing types should be supplemented with the outsourcing in business planning and in the sphere of internal audit (before the revision audit of the financial statements) [7]. We should note that outsourcing in the business planning is not very developed on the domestic enterprises, because this type of activity is of a strategic character and is one of the most important for the business entity activities.

The financial outsourcing use stipulate for the range of advantages appearance, namely:

- costs reduction (the cost of outsourcing company services is usually lower than out-ofpocket expenses on the financial department maintenance);

- quality improvement of the performance of financial functions delegated (outsourcer's employees better understand changes in legislation and innovative projects as they specialize in the realization of certain functions);

- an increase of financial information objectivity (reducing the shenanigans risk) [1, p. 272];

- a possibility to concentrate on the execution of one's main duties.

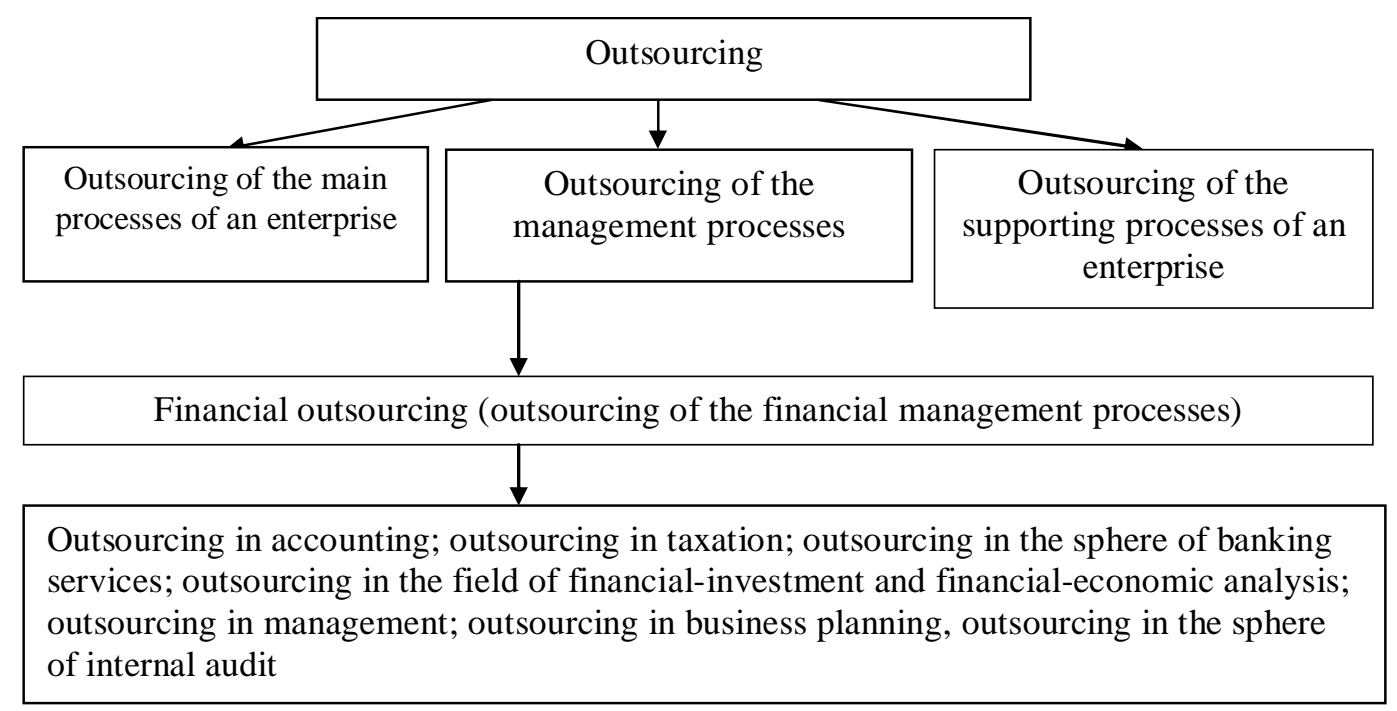

Fig. 1. Interconnection and a place of the financial outsourcing in the enterprise outsourcing activities 
But along with the advantages, delegation of financial functions to outsourcer may also lead to the appearance of a range of risks, among which: the risk of outsourcer's untimeliness in his functions realization; the risk of getting low-quality services from outsourcer; the risk of confidential information disclosure by outsourcer.

Therefore, we may conclude that the financial outsourcing is an important instrument of an enterprise-customer activities optimization. The decision to delegate financial functions implementation to the third-party organization is primarily related to the priorities of the enterprise activities, as well as with the ability to get a positive economic effect from the outsourcing.

Since the outsourcing activities of an enterprise-customer may provide for the delegation of several functions to outsourcer at once, it is necessary to determine separately the efficiency of each function delegated on outsourcing with the aim of further evaluation of final results of enterprise-customer cooperation with one or several outsourcing companies. That is why, it is appropriate to calculate indicators both by the separate types of outsourcing and in general while evaluating the efficiency of outsourcing activities. During the comprehensive analysis of an outsourcing activities effectiveness, one should estimate not only the quantitative change of production parameters, but qualitative changes in the enterprise functioning and the resulting increase in income and profit. It is also important that while analyzing the substantiation of the certain functions delegation on outsourcing, one should consider both changes in the financial and economic condition of an enterprise-customer and the changes in influence of factors that determine it. Therefore, during the analysis process one should possess not only the financial, but also nonfinancial information concerning the enterprise outsourcing activities effectiveness [3, p. 173].

The formation of the indicators system for determining the economic efficiency of enterprises outsourcing requires a comprehensive analysis of its usage purpose and aims, as well as the evaluation of possibility and validity of internal organizational changes after the functions delegation to outsourcer.
The analysis of practical experience in determining the economic efficiency of outsourcing activities shows that enterprises-customers, as a rule, compare only the labour costs of employees, whose functions they plan to delegate to outsourcer, with general costs of outsourcing. However, this approach does not consider all the expenses, related to the function performance by the own forces, which, in addition to labour costs, include expanses for employees' vacations and sick leaves payments, the costs of production process organizing, the corresponding taxations, etc. So the evaluation of the outsourcing activities economic efficiency should be realized holistically, considering all the incomes and expenses of an enterprise, which arise in the process of certain functions delegation to outsourcing company. While measuring the enterprise costs related to outsourcing activities realization, one should take into the account not only the market price of outsourcer's services, but also the transactional costs that arise in the process of delegating a function, in our case - the financial one. Therefore, in fact, the cost of the outsourcing service for an enterprise consists of two main parts: the cost of service declared by outsourcer, and the sum of accompanying transactional costs that arise in the process of outsourcing introduction into the enterprise activities.

Out of this, it can be said that outsourcing may be considered as effective, if the difference between the own costs of machine-building enterprise for the function implementation and the cost of outsourcer's services exceeds the sum of transactional costs related to the outsourcing agreement implementation. To analyze carefully the enterprise costs when using the outsourcing and to outline the special features of determining its economic efficiency, one should, first of all, characterize the enterprise costs on the main stages of outsourcing agreement preparation and implementation (see Tab. 1).

While analyzing the financial outsourcing economic efficiency, one should, first of all, compare the customer's relevant costs for the certain function implementation with the related costs of an outsourcing company. Relevant costs are the costs, the amount of which may change due to the decision-making [7]. If the certain function is 
being delegated for an outsourcing, these costs should include all the variable costs of enterprisecustomer related to this function realization. Most of fixed costs are usually not relevant, because their amount during establishing the cooperation with outsourcer is often static. If the outsourcing costs are below the relevant costs for the certain function or business process realization through one's own efforts, then the outsourcing usage may be considered as profitable.

Table 1

Expenses of an enterprise-customer, which arise at every stage of financial functions outsourcing planning and implementation*

\begin{tabular}{|c|c|c|}
\hline \multicolumn{2}{|c|}{$\begin{array}{l}\text { Stages of outsourcing planning and } \\
\text { implementation }\end{array}$} & Types of expenses \\
\hline \multirow{2}{*}{ 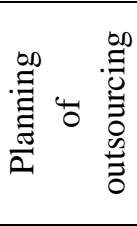 } & $\begin{array}{l}\text { Expediency evaluation of } \\
\text { functions delegation on } \\
\text { outsourcing }\end{array}$ & $\begin{array}{l}\text { Costs to assess the risks related to an outsourcing implementation; } \\
\text { costs associated with identifying the opportunities of outsourcing use; } \\
\text { costs for outsourcing mechanism development, etc. }\end{array}$ \\
\hline & $\begin{array}{l}\text { Selecting an outsourcer for the } \\
\text { separate function delegating }\end{array}$ & $\begin{array}{l}\text { Costs of outsourcing services market monitoring, costs of a tender } \\
\text { organizing, costs of preparing the negotiations, etc. }\end{array}$ \\
\hline \multirow{4}{*}{ 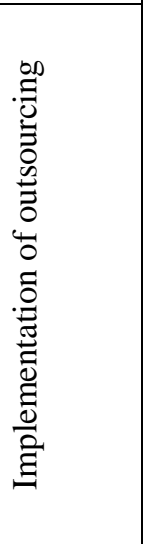 } & $\begin{array}{l}\text { Establishing the individual } \\
\text { contract }\end{array}$ & $\begin{array}{l}\text { Costs of information transfer and accessing, consultations and } \\
\text { negotiations costs, costs for transactions documentation. }\end{array}$ \\
\hline & $\begin{array}{l}\text { Delegation of the separate } \\
\text { function to outsourcer }\end{array}$ & $\begin{array}{l}\text { The costs of activities transformation, the costs of changes in } \\
\text { operating conditions and in labour collective's composition at an } \\
\text { enterprise. }\end{array}$ \\
\hline & $\begin{array}{l}\text { Monitoring of outsourcer's } \\
\text { performing of its tasks, } \\
\text { deviations correcting }\end{array}$ & $\begin{array}{l}\text { The costs for monitoring and control of the outsourcing operations } \\
\text { implementation process, the costs for economic analysis of contract } \\
\text { terms fulfilment, the costs of correcting measures implementation. }\end{array}$ \\
\hline & $\begin{array}{l}\text { The summary analysis of } \\
\text { economic efficiency of the } \\
\text { separate function delegation on } \\
\text { outsourcing }\end{array}$ & $\begin{array}{l}\text { Costs for the summary analysis implementation; losses caused by the } \\
\text { outsourcer in the event of failure to comply with the terms of the } \\
\text { contract; the costs related to termination of the relationship with an } \\
\text { outsourcer; the costs for business reorganization, etc. }\end{array}$ \\
\hline
\end{tabular}

* Note: developed by authors on the basis of [2, p.45]

We should mention that this approach can be implemented only in the short-term period, as the fixed costs may also undergo the certain changes after the function delegation to outsourcer. That is why, if the costs of the function implementation by outsourcer exceeds the customer's variable costs, this still does not completely indicate that the use of outsourcing is inexpedient. During the general analysis implementation one should also consider the opportunities for the fixed costs reduction in future, qualitative changes at the enterprise, as well as the ability to get the additional profit in case of outsourcing implementation.

Therefore, in the process of outsourcing activities economic efficiency analysis, one should calculate the expenditure efficiency indicator, which characterizes the sum of costs saving in case of outsourcing implementation at the machine- building enterprise. The amount of such saving can be calculated by the following formula:

$$
V e=\sum_{i=1}^{n} V b_{i}-\sum_{i=1}^{n} V f_{i}-V v z-R,
$$

where $V e$ - the expenditure efficiency of the outsourcing activity, UAH., $V b_{i}$ - the cost of the ith function implementation before the outsourcing use, UAH., $V f_{i}$ - the cost of the i-th function implementation by the outsourcer, UAH, $V v z-$ costs of the measures concerning the outsourcing activities implementation, UAH, $R$ - the expected volume of losses (at the realization of risks, depends on the probability of risk realization and the amount of costs), UAH.

In the event the $V e>0$, the implementation of outsourcing activities is justified from a cost point of view. But if $V e<0$, the implementation of outsourcing activities is unjustified from a cost 
point of view. Provided that $V e=0$, there will not be any cost savings from the outsourcing activities implementation.

While analyzing the economic efficiency of outsourcing activities, it is important to evaluate the influence of outsourcing implementation risks on the results of cooperation between the enterprise-customer and the outsourcer, as the calculated economic benefit from the outsourcing use may decrease after the risk situation onset.

At the same time, the improvement of financial results is not always the purpose of outsourcing implementation. In some cases, the use of this management instrument is directed at the improvement of enterprise functioning qualitative characteristics, and consequently, at its competitive abilities increase in future. In this case, during the process of the outsourcing economic efficiency analysis one should evaluate the qualitative parameters of the cooperation and the outsourcer's capabilities to provide the relevant services [6].

Outsourcing activities of the enterprisecustomer may influence not only at its quantitative results, but also at changes in the labour and material resources use environment, as well as the operation process organizing in general. So while determining the economic efficiency of outsourcing activities, it is important to assess the qualitative changes resulting from:

- quality enhancement of functions implementation;

- the outsourcer's experience use;

- optimizing the management system;

- optimizing the organizational structure and so on.

Qualitative effect of the outsourcing activities implementation can be measured using the expert evaluation methods or taking to consideration changes of machine-building enterprise financial results in future. Therefore, the improvement of the production quality will in time result in the profits increase, and the organizational structure optimizing - in the enhancing of information flows state.

When analyzing the economic efficiency of outsourcing activities, it is expedient to compare the enterprise financial result before and after the outsourcing implementation. In this case, the main and rather contradictory task for the enterprise is to choose the system of evaluation indicators [4].

To measure the quantitative result of the outsourcing activities implementation, they use the quantitative indicators that reflect the cost side of the enterprise activities. In the economic literature they are being divided into absolute indicators, using which the one can analyze the deviations of actual volume of expenses, incomes and profit from the base values, and then conclude about the outsourcing implementation effectiveness, and the relative ones' that enable to find the ratio between the enterprise economic activities and evaluate its economic potential at all.

The selection of quantitative indicators system of outsourcing economic efficiency depends on the aim of the outsourcing use, as well as on setting the quantitative requirements to its expected results. Therefore, the determination of the outsourcing activities implementation quantitative effect, as with the qualitative one, depends on the form and types of outsourcing, which is being realized on a case-by-case basis. Different types of outsourcing are characterized by their organizational features and the implementation process, ultimately influencing the selection of parameters for determining the impact of outsourcing on the enterprise-customer activities. The evaluation of economic efficiency of enterprise-customer outsourcing activities using the indicators by the separate types of outsourcing enable determining how these outsourcing types influence on its performance. We should note that while calculating the mentioned indicators, the one must consider only those changes that arise on an enterprise as a result of the delegating to the thirdparty executor the certain function or a group of functions within the individual outsourcing type.

Given that the financial functions relate to the outsourcing of management processes, we have identified the list of key indicators that are appropriate to use while determining the efficiency of partial or absolute delegation of the financial functions to outsourcer (Tab. 2).

Since the efficiency of the enterprise outsourcing activities is determined by the sum of effects from the separate functions delegation on outsourcing, as well as by means of calculation and comparison of the enterprise management 


\section{Chushak-Holoborodko A., Didukh O., Zaderetska R.}

effectiveness generalized indicators, the process of this activity economic efficiency evaluation should end with the identifying the general indicators of enterprise functioning economic efficiency. The main among them are the indicators of business activity, profitability, EVA and so on.
Evaluation of economic efficiency of financial functions outsourcing has been implemented by the example of the following enterprises: "Skiper" Ltd., "Optima Trading" Ltd. and "Kaleidoskop" Ltd. The investigation results are represented in the Table 3.

Table 2

Key indicators of evaluating the economic efficiency of enterprise-customer's delegating the financial management functions to outsourcing*

\begin{tabular}{|c|c|c|c|}
\hline Indicators & Calculation formulas & Best value & Notation conventions \\
\hline \multicolumn{4}{|c|}{ Financial sustainability indicators } \\
\hline $\begin{array}{l}\text { Change in the } \\
\text { enterprise financial } \\
\text { sustainability }\end{array}$ & $\Delta I_{f s} f=\frac{I_{f s} f}{I_{f s} b}$ & $>1$ & $\begin{array}{l}I_{f s} f, I_{f s} b-\text { corresponding values of } \\
\text { financial sustainability indicators after } \\
\text { and before the financial management } \\
\text { functions delegation on outsourcing }\end{array}$ \\
\hline $\begin{array}{l}\text { Change in the } \\
\text { enterprise autonomy } \\
\text { ratio }\end{array}$ & $\Delta I_{a r} f=\frac{I_{a r} f}{I_{a r} b}$ & $>1$ & $\begin{array}{l}I_{a r} f, I_{a r} b-\text { corresponding values of } \\
\text { autonomy ratios after and before the } \\
\text { financial management functions } \\
\text { delegation on outsourcing }\end{array}$ \\
\hline \multicolumn{4}{|c|}{ Liquidity and solvency indicators } \\
\hline $\begin{array}{l}\text { Change in the } \\
\text { enterprise general } \\
\text { liquidity }\end{array}$ & $\Delta I_{g l} f=\frac{I_{g l} f}{I_{g l} b}$ & $>1$ & $\begin{array}{l}I_{g l} f, I_{g l} b-\text { corresponding values of } \\
\text { general liquidity indicators after and } \\
\text { before the financial management } \\
\text { functions delegation on outsourcing }\end{array}$ \\
\hline $\begin{array}{l}\text { Change in the } \\
\text { enterprise fast liquidity }\end{array}$ & $\Delta I_{f l} f=\frac{I_{f l} f}{I_{f l} b}$ & $>1$ & $\begin{array}{l}I_{f l} f, I_{f l} b-\text { corresponding values of fast } \\
\text { liquidity indicators after and before the } \\
\text { financial management functions } \\
\text { delegation on outsourcing }\end{array}$ \\
\hline $\begin{array}{l}\text { Change in the } \\
\text { enterprise absolute } \\
\text { liquidity }\end{array}$ & $\Delta I_{a l} f=\frac{I_{a l} f}{I_{a l} b}$ & $>1$ & $\begin{array}{l}I_{a l} f, I_{a l} b-\text { corresponding values of } \\
\text { absolute liquidity indicators after and } \\
\text { before the financial management } \\
\text { functions delegation on outsourcing }\end{array}$ \\
\hline \multicolumn{4}{|c|}{ Profitability indicators } \\
\hline $\begin{array}{c}\text { Change in the return on } \\
\text { equity }\end{array}$ & $\Delta R O E_{f}=\frac{R O E_{f}}{R O E_{b}}$ & $>1$ & $\begin{array}{l}R O E_{f}, R O E_{b}-\text { corresponding values of } \\
\text { return on equity indicators after and } \\
\text { before the financial management } \\
\text { functions delegation on outsourcing }\end{array}$ \\
\hline $\begin{array}{l}\text { Change in profitability } \\
\text { of the enterprise } \\
\text { activities }\end{array}$ & $\Delta P e a_{f}=\frac{P e a_{f}}{P e a_{b}}$ & $>1$ & $\begin{array}{l}P e a_{f}, P e a_{b}-\text { corresponding values of } \\
\text { net margin indicators after and before the } \\
\text { financial management functions } \\
\text { delegation on outsourcing }\end{array}$ \\
\hline $\begin{array}{l}\text { Change in the } \\
\text { enterprise return on } \\
\text { assets }\end{array}$ & $\Delta R O A_{f}=\frac{R O A_{f}}{R O A_{b}}$ & $>1$ & $\begin{array}{l}R O A_{f}, R O A_{b}-\text { corresponding values of } \\
\text { return on assets indicators after and } \\
\text { before the financial management } \\
\text { functions delegation on outsourcing. }\end{array}$ \\
\hline
\end{tabular}

Note: developed by authors on the basis of [5, p.230]. 
The results of outsourcing activities economic efficiency evaluation at machine-building enterprises*

\begin{tabular}{|c|c|}
\hline $\begin{array}{c}\text { Enterprise name (types of } \\
\text { functions that are being } \\
\text { delegated on outsourcing) }\end{array}$ & \multicolumn{1}{c|}{$\begin{array}{c}\text { Indicators of outsourcing activities economic } \\
\text { efficiency evaluation }\end{array}$} \\
\hline $\begin{array}{c}\text { "Skiper" Ltd. } \\
\text { (outsourcing in accounting and } \\
\text { financial-economic analysis) }\end{array}$ & $\begin{array}{c}\text { Change in the enterprise financial sustainability } \Delta I_{f l} f=1.02 \\
\text { Change in the enterprise general liquidity } \Delta I_{g i} f=1.05 \\
\text { Change in the return on equity } \Delta R O E_{f}=1.05 \\
\text { Change in the profitability of enterprise activities } \operatorname{Re} a_{f}=1.03 \\
\text { Change in the return on assets } \Delta R O A_{f}=1.04 \\
\text { The values of the indicators signal the positive use of outsourcing }\end{array}$ \\
\hline $\begin{array}{c}\text { "Optima Trading" Ltd } \\
\text { (outsourcing in accounting) }\end{array}$ & $\begin{array}{l}\text { Change in the profitability of enterprise activities } \operatorname{Re} a_{f}=1.01 \\
\text { Change in the return on equity } \Delta R O E_{f}=1.02 \\
\text { The values of the indicators signal the positive use of outsourcing }\end{array}$ \\
\hline $\begin{array}{c}\text { (outsourcing in accounting) } \\
\text { Change in the profitability of enterprise activities } \operatorname{Re} a_{f}=1.02 \\
\text { Change in the return on equity } \Delta R O E_{f}=1.0\end{array}$ \\
\hline \begin{tabular}{c} 
The values of the indicators signal the positive use of outsourcing \\
\hline
\end{tabular}
\end{tabular}

*Note: authors' calculation.

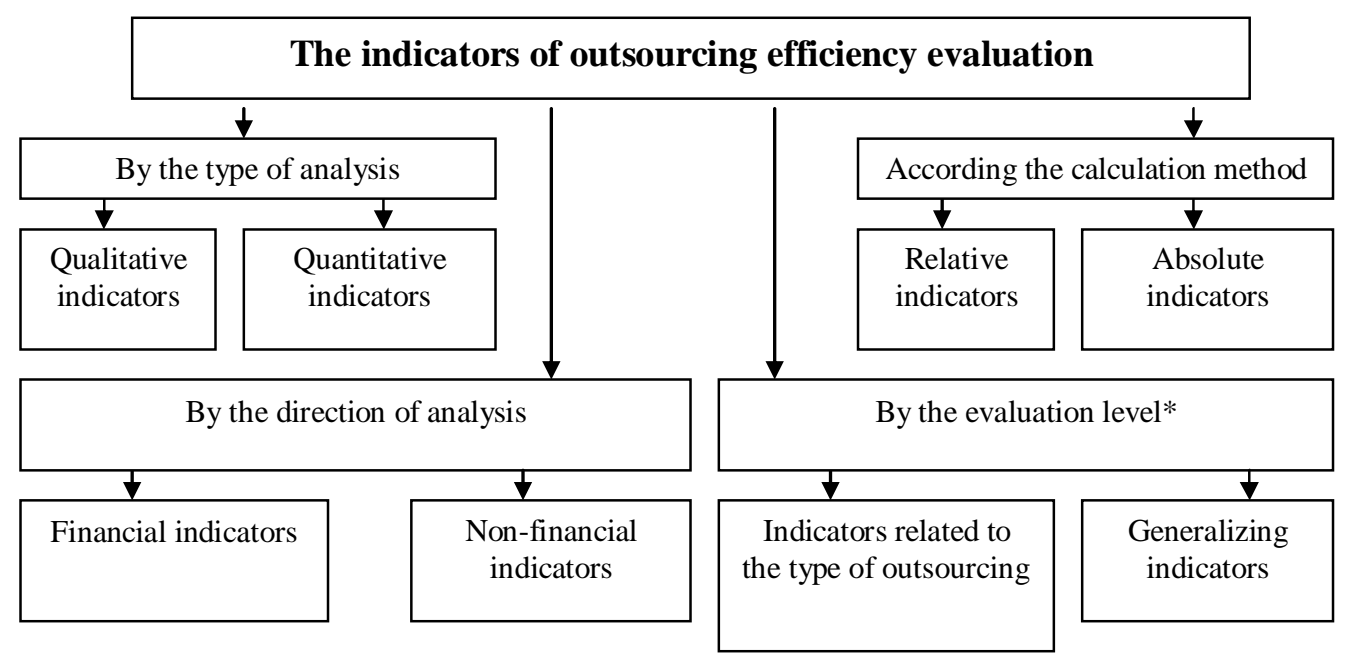

Fig. 2. Indicators for evaluating the economic efficiency of outsourcing activities implementing at a machine-building enterprise

Note: supplemented by authors

So, the evaluation of outsourcing activities economic efficiency at machine-building enterprises can be realized both on the basis of specific indicators within the separate types of outsourcing and with the help of generalizing ones. In Fig. 2 the list of indicators groups of economic efficiency evaluation of outsourcing activities realization at the machine-building enterprise is presented.
Considering what has been said above, three conceptual approaches to determining the economic efficiency of financial outsourcing by an enterprise-customer can be singled out: on the basis of calculating the outsourcing cost effectiveness. This indicator is reasonable to use when the purpose of outsourcing is to reduce costs, provided that the income of the enterprise will be unchanged; by comparing the growth rates of the 


\section{Chushak-Holoborodko A., Didukh O., Zaderetska R.}

income, profit and costs of the enterprise- customer before and after implementing the outsourcing activities; with the use of estimates for both individual types of outsourcing, and generalizing.

As a conclusion, it should be noted that the formation of an indicators system for assessing the economic efficiency of outsourcing activities implementing by the enterprise-customer requires managers to develop and implement a number of managerial decisions, depending on the type and form of outsourcing. Evaluation of the outsourcing implementation results should be comprehensive and consider all aspects of cooperation between the customer and the outsourcer both during the establishing and within the period of fulfillment of the outsourcing agreement conditions. It is important to develop a risk assessment system for a financial outsourcer in the future, which will allow us to calculate more accurately the cost savings after delegating the functions to the outsourcer.

\section{References}

1. Kosmina V. (2014). Offshore outsourcing and export of transnational companiesfrom newly industrialised countries of Asia. Austrian Journal of Humanities and Social Sciences, 271-275

2. Logvinova O. (2013). Financial outsourcing: the essence, trends and prospects of development in Ukraine. Ekonomichna stratehiya I perspektyvy rozvytku sfery torhivli ta posluh [Economic strategy and prospects for the development of trade and services], 1(2), 40-48. [in Ukrainian]

3. Omel'chenko L., Laktyonova O., Mandra N. (2017) SME development in Ukraine: outsourcing aspect. Skhidna Yevropa: ekonomika, biznes ta upravlinnya [Eastern Europe: Economics, Business and Management], 3, 170-177 [in Ukrainian]

4. Omel'chenko L., Laktyonova O., Kalendzhyan, O. (2016) Fynansovyy autsorsynh [Financial outsourcing]. Maryupol': PHTU [in Russian]

5. Partyn H. \& Didukh O. (2013) Metrics formation of effectiveness evaluation of outsourcing application in enterprise business activity [Accounting and analytical support of the management system of an enterprise: collective monograph / Edited by: prof. A. Zahorodniy and prof. H. Ronek.] (pp.218-235). Lviv: Publishing House of Lviv Politechnic.

6. Ysavnyn, A. H. (2013) Osobennosty prymynenyia proyzvodstvennoho autsorsynha: monohrafyia [Features of application outsourcing production: monograph], LAP LAMBERT Academic Publishing. [in Russian]

7. 8cent-emails (2014) Prepiatstvyia dlia povyshenyia effektyvnosty vneshneekonomycheskoj deiatel'nosty kompanyy [Obstacles to improve the efficiency of foreign economic activity of the company], http://8cent-emails.com/prepjatstvija-dljapovyshenija-jeffektivnosti-vneshnejekonomicheskojdejatelnosti-kompanii [in Russian]. 